\title{
Parallel Hybrid Gas-Electric Geared Turbofan Engine Conceptual Design and Benefits Analysis
}

\author{
Authors: \\ Charles Lents ${ }^{1}$, Larry Hardin ${ }^{2}$, Jonathan Rheaume ${ }^{3}$ \\ United Technologies Research Center, East Hartfod, CT, 06108 \\ and \\ Lee Kohlman ${ }^{4}$ \\ NASA Glenn Research Center, Hampton, VA, 23681
}

The conceptual design of a parallel gas-electric hybrid propulsion system for a conventional single aisle twin engine tube and wing vehicle has been developed. The study baseline vehicle and engine technology are discussed, followed by results of the hybrid propulsion system sizing and performance analysis. The weights analysis for the electric energy storage \& conversion system and thermal management system is described. Finally, the potential system benefits are assessed.

\begin{tabular}{ll} 
ADP & aero design point \\
Alt & altitude \\
AOC & air oil cooler \\
Bat & battery \\
BPR & bypass ratio \\
Brg & bearings \\
$c G T F$ & conventional geared turbofan \\
CoO & concept of operations \\
$C O R S Z$ & core corrected flow (lbm/sec) \\
DOC & direct operating cost \\
$E E S \& C$ & electric energy storage and conversion \\
$E T A C$ & core thermal efficiency \\
$F a n D S$ & Fan Drive System \\
$F O C$ & fuel oil cooler \\
$F P$ & fuel pump \\
$F P R$ & fan pressure ratio \\
$G b x$ & gearbox \\
$G T F$ & geared turbofan \\
$h G T F$ & hybrid geared turbofan \\
$H S$ & high spool \\
$I S A$ & international standard atmosphere \\
L/D & lift/drag ratio \\
LH2 & liquid hydrogen \\
& \\
\hline
\end{tabular}

\footnotetext{
${ }^{1}$ Principal Engineer, Thermal Management Group, Thermal \& Fluid Sciences Department, United Technologies Research Center, 411 Silver Lane, MS 129-89, East Hartford CT 06108, AIAA Senior Member

${ }^{2}$ Staff Engineer, Aerodynamics Group, Thermal \& Fluid Sciences Department, United Technologies Research Center, 411 Silver Lane, MS 129-89, East Hartford CT 06108, AIAA Senior Member

${ }^{3}$ Senior Engineer, Thermal Management Group, Thermal \& Fluid Sciences Department, United Technologies Research Center, 411 Silver Lane, MS 129-89, East Hartford CT 06108

${ }^{4}$ Research Aerospace Engineer, Rotating and Drive Systems Branchy, Glenn Research Center, 1 North Dryden Street, MS 442, Hampton VA 23681, AIAA Member
} 


$\begin{array}{ll}L S & \text { low spool } \\ M a c h & \text { mach number } \\ M C L & \text { maximum climb thrust } \\ M C R & \text { maximum cruise } \\ M D & \text { motor drive } \\ M G & \text { motor/generator } \\ M T O & \text { maximum takeoff } \\ O P R & \text { operating pressure ratio } \\ P E M F C & \text { proton exchange membrane fuel cell } \\ R C C & \text { ram coolant cooler } \\ S G & \text { starter-generator } \\ S L S & \text { Sea Level Static } \\ S U G A R & \text { subsonic ultra green aircraft research } \\ T A M B & \text { temperature above standard ambient }\left({ }^{\circ} \mathrm{F}\right) \\ T M S & \text { thermal management system } \\ T O G W & \text { takeoff gross weight } \\ T S F C & \text { thrust specific fuel consumption }(\mathrm{lbm} / \mathrm{hr} / \mathrm{hp}) \\ T 4 & \text { turbine inlet temperature }\left({ }^{\circ} \mathrm{F}\right)\end{array}$

\section{Introduction}

This NASA-funded program has produced the notional concept of operations and conceptual design of a parallel gas-electric hybrid propulsion system. The study has been constrained to a conventional single aisle twin engine tube and wing vehicle. Additionally, the propulsion system architecture has been constrained to a conventional high bypass ratio propulsor where the propulsion fan can be driven by both the low pressure turbine and a fan spoolmounted motor/generator. In the selected concept of operations (CoO), the low spool (LS) motor/generator is used as a motor for boost power during takeoff and climb only, enabling the engine core to be sized at the MCR (maximum cruise) condition. During cruise, the LS motor/generator can be operated in generate mode to charge the batteries for idle descent, ground idle or for the next mission takeoff and climb segment. The subsystems' electric power needs are met by stored electric power when the LS motor/generator is in motor mode and by the LS motor/generator when it is not being used as a motor, i.e., in generate mode. This $\mathrm{CoO}$ selection drove the remaining propulsion system design parameters. The hybrid geared turbofan (GTF) (hGTF) with a core sized for cruise has the same MCR overall pressure ratio (OPR) (59.8) as a conventional GTF (cGTF), but with a 17\% smaller core flow. With the smaller core, the hGTF requires a $2.1 \mathrm{MW}$ motor to provide required takeoff thrust. $1495 \mathrm{~kW}$-hrs of stored energy are required by both engines for the takeoff and climb segments.

With current technology batteries $(170 \mathrm{~W}-\mathrm{hr} / \mathrm{kg})$, electric components and thermal management system components, an hGTF-based airplane has much higher mission fuel burn than a cGTF based airplane for a $900 \mathrm{~nm}$ direct operating cost (DOC) mission. However, with improvements in electric components power density and thermal management systems capability, a $\sim 5 \%$ reduction in Jet-A fuel consumption for the DOC mission is possible.

\section{Study Baseline Vehicle and Engine}

The baseline vehicle is the Boeing defined N+4 2035 Refined SUGAR [1,2] airframe powered by a second generation conventional GTF (cGTF) engine. This is a conventional tube and wing vehicle with wing span constrained to fit between gates as configured today. Advanced materials for a lightweight, high L/D airframe are assumed. A comparison between a modern single aisle 737-800 reference and the Refined SUGAR baseline airframe is provided in Table 1 and Error! Reference source not found..

Table 1: 737 Compared to Refined SUGAR N+4 Airframe

\begin{tabular}{|l|c|c|}
\hline Sizing Level & $\begin{array}{c}737-800 \\
\text { Reference }\end{array}$ & $\begin{array}{c}\text { N+4 Refined } \\
\text { Sugar Baseline }\end{array}$ \\
\hline Passengers/Class & $154 /$ DUAL & $154 /$ DUAL \\
\hline Max Takeoff Gross Weight $(\mathrm{lbm})$ & 174200 & 136412 \\
\hline Operating Empty Weight $(\mathrm{lbm})$ & 91660 & 79213 \\
\hline Fuel Capacity $(\mathrm{lbm})$ & 46063 & 26513 \\
\hline Wing Area $\left(\mathrm{ft}^{2}\right)$ & 1341 & 1,358 \\
\hline
\end{tabular}

2

American Institute of Aeronautics and Astronautics 


\begin{tabular}{|l|c|c|} 
Aspect Ratio (Effective) & 9.45 & 11.07 \\
\hline Cruise L/D @ Optimal CL & 17.7 & 21.5 \\
\hline Design Mission Range (nm) & 3,149 & 3,149 \\
\hline DOC Mission Range (nm) & 900 & 900 \\
\hline Cruise Mach & 0.79 & 0.74 \\
\hline
\end{tabular}
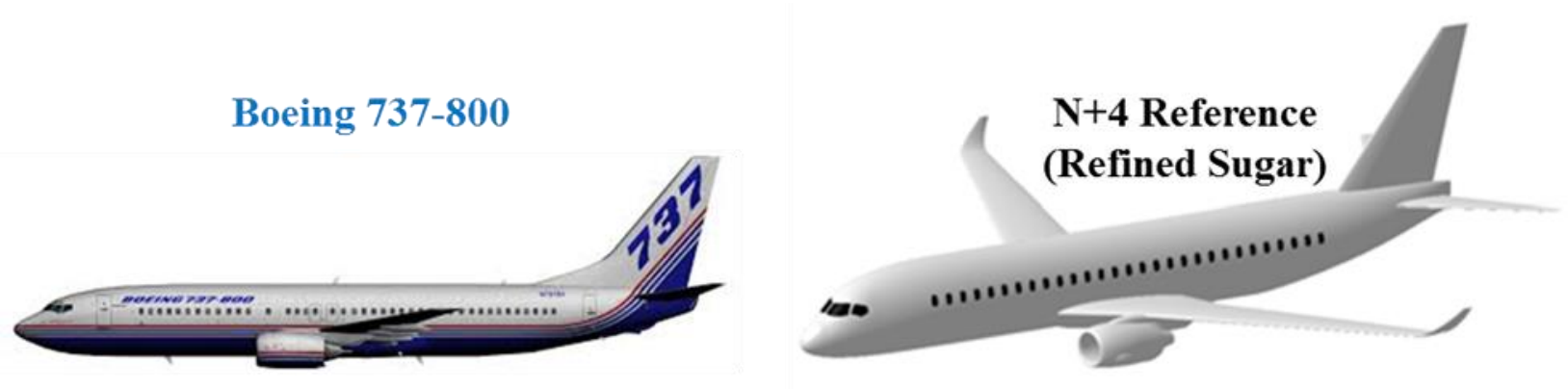

Figure 1: 737 Compared to Refined SUGAR N+4 Airframe

The choice of a second generation GTF for the baseline vehicle is driven by the long horizon 2035 entery into service for the baseline vehicle. The cGTF has been sized for the baseline refined SUGAR aircraft. Design and performance parameters are provided in Table 2.

Table 2: cGTF Design and Performance Parameters

\begin{tabular}{|c|c|c|c|c|c|c|c|c|c|c|c|c|}
\hline & $\begin{array}{l}\text { Alt } \\
(\mathrm{kft})\end{array}$ & Mach & $\begin{array}{c}\Delta \mathrm{T}_{\mathrm{AMB}} \\
(\mathrm{F})\end{array}$ & $\begin{array}{l}\text { Req } \\
\text { Thrust }\end{array}$ & $\begin{array}{l}\text { Actual } \\
\text { Thrust }\end{array}$ & TSFC & $\begin{array}{c}\text { Norm } \\
\text { CORSZ }\end{array}$ & OPR & FPR & BPR & $\begin{array}{c}\text { Norm } \\
\text { T4 }\end{array}$ & ETAC \\
\hline ADP & 35 & 0.74 & 0 & 3145 & 3145 & 0.480 & 1.01 & 55.2 & 1.29 & 18.1 & 0.85 & 0.527 \\
\hline $\mathrm{MCL}$ & 35 & 0.74 & 18 & 3930 & 3930 & 0.499 & 1.00 & 64.6 & 1.35 & 17.0 & 0.96 & 0.535 \\
\hline MTO & 0 & 0.25 & 27 & 16592 & 17046 & 0.301 & 0.97 & 54.3 & 1.28 & 18.6 & 1.00 & 0.503 \\
\hline SLS & 0 & 0 & 27 & 21943 & 23894 & 0.204 & 0.97 & 51.6 & 1.27 & 18.1 & 0.97 & 0.494 \\
\hline MCR & 35 & 0.74 & 0 & 3538 & 3538 & 0.479 & 1.01 & 59.8 & 1.32 & 17.6 & 0.89 & 0.535 \\
\hline
\end{tabular}

ADP - Aero Design Point, MCL - Maximum Climb Thrust, MTO - Maximum Takeoff Thrust, SLS - Sea Level Static, MCR - Maximum Cruise Thrust, Alt - altitude, Mach - mach number, $\triangle \mathrm{TAMB}$ - temperature above standard ambient (F), TSFC - thrust specific fuel consumption (lbm/hr/hp), CORSZ - core corrected flow (lbm/sec), OPR - operating pressure ratio, FPR - fan pressure ratio, BPR bypass ratio, T4 - turbine inlet temperature (F), ETAC - Core thermal efficiency

\section{Propulsion System Sizing and Performance Analysis General Guidelines}

The architecture of a cGTF drives the engine design point to occur at takeoff or top of climb. To make required thrust at these points, the engine core is run at the maximum T4 (turbine inlet temperature) limit, where peak efficiency is achieved. This condition also sizes engine core flow. As a result, at cruise the engine is run significantly below the long life maximum T4 limit. By adding external power during takeoff and climb to the low spool, the engine can be designed for higher $\mathrm{T} 4$ at the cruise condition which will improve the core efficiency.

For consistency of comparison, the FPR for the hGTF is set at the same values as that for the cGTF, as the hGTF electric boost capability has not been found to provide any low FPR enabling advantage over the cGTF. Other parameters, BPR, T4 and core size namely, have been optimized specifically for each engine. Four sizing points conditions are considered in the design of a propulsion system; 1) ADP - the aerodynamic design point which is cruise at 35k feet in a standard atmosphere, 2) MCL - max climb thrust at the same altitude and Mach number as the ADP but with the temperature at ISA+18F, 3) MTO - max takeoff thrust at sea level, M=0.25, ISA+27F, 4) SLS sea level static thrust at ISA+27F). The cGTF engine is sized as follows.

1. The fan area is set to give a target corrected flow per unit area at the MCL sizing point. 
2. The core flow is set so that T4 limits are not exceeded at MCL, MTO, or SLS. For the cGTF, the MCL sizing point sets the core flow, and T4 at MTO and SLS are slightly below the limits.

For the hybrid GTF, the procedure is slightly different. Error! Reference source not found. provides the results of the sizing study.

1. The fan area is set to give a target corrected flow per unit area at the MCL sizing point. This area will be slightly different than for the cGTF because the smaller core enabled by adding electric power for takeoff and climb will yield a higher bypass ratio. Notice that both the cGTF and hGTF bars of Figure 2 for MCL are at the T4/T4max limit. This shows that MCL is the sizing point for the cGTF. For the hGTF, this is by design as explained in Step 3 below.

2. The core flow is set so that with no additional low spool power T4, does not exceed the MCL T4 limit at MCR (MCR thrust is defined as 93\% of the MCL thrust). Notice in Figure 2 that this MCL T4/T4max limit of 0.96 is less than the absolute T4/T4max limit of 1.0 which occurs at max takeoff. This is because MCL and MCR can occur over an extended time, so a lower T4 limit is imposed at these conditions. The MCL T4/T4max limit is used at MCR conditions as the engine is not expected to cruise at the max cruise condition very often. This procedure yields a smaller core that will not produce enough power to drive the fan at takeoff and climb conditions.

3. Once the engine has been sized, the takeoff and climb segments are considered. The T4/T4max is set at the limit (1.0 at max takeoff and 0.96 at max climb) and the developed thrust is determined. As a result, the hGTF MTO and MCL bars are at exactly the T4/T4Max limits. Power is then added to the low spool until the thrust developed by the cGTF is achieved. This determines the maximum added power required and thus provides the rating for the low spool motor/generator. For climb points between MTO and MCL, a power addition schedule is developed that closely replicates the climb thrust of the cGTF. As it turns out, this schedule is a simple linear function of altitude.

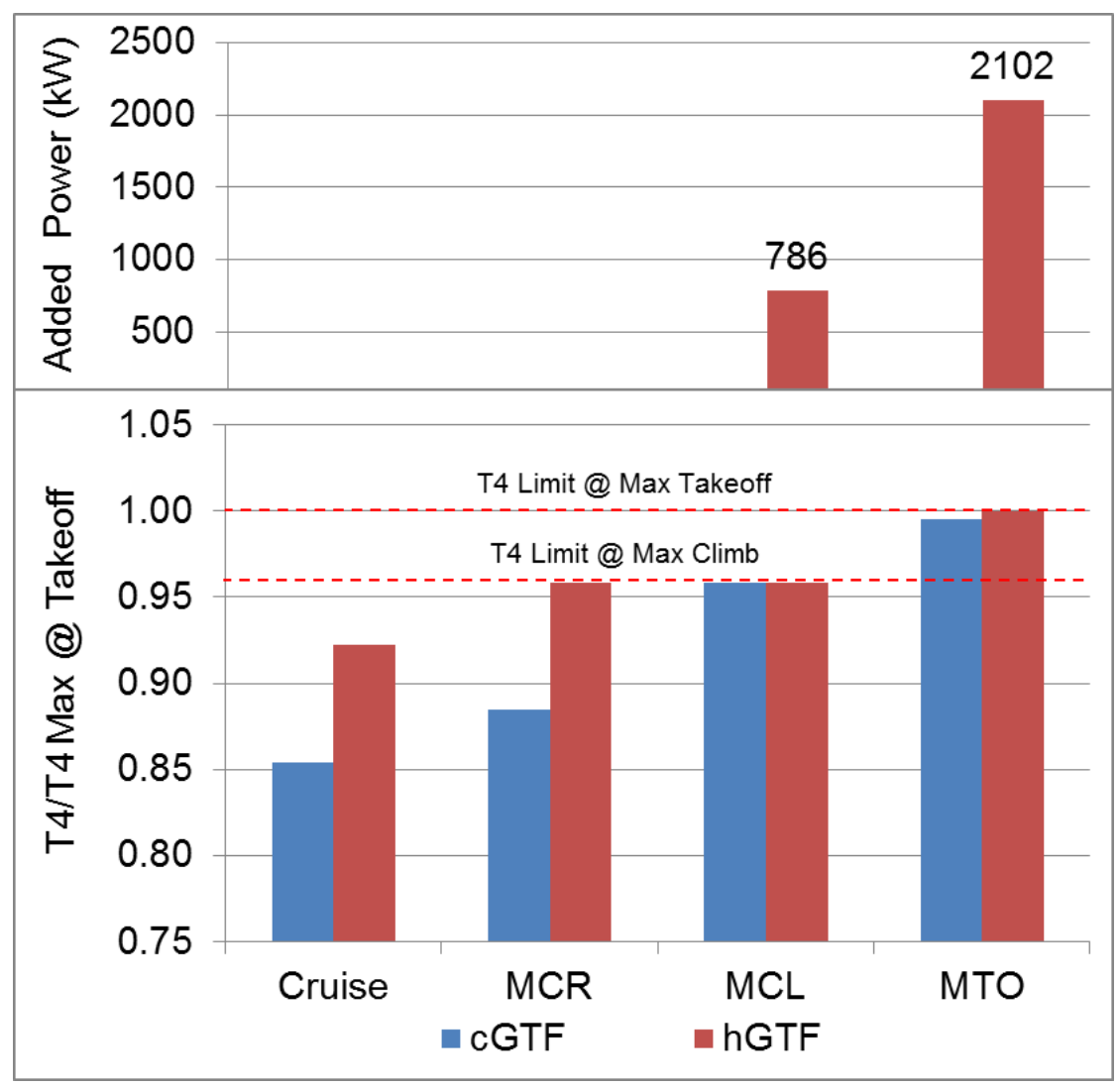

Figure 2: hGTF Sizing Results 
Error! Reference source not found. shows that the added power required to make thrust at the T4 limited points of MTO and MCL are $2102 \mathrm{~kW}$ and $786 \mathrm{~kW}$ respectively. Thus, a $2102 \mathrm{~kW}$ motor is required for the hGTF propulsion system. With the hGTF engine size at higher T4/T4max than the conventional GTF for cruise operation, the engine achieves a lower TSFC at cruise. Error! Reference source not found. provides a normalized comparison. The improvement is estimated at $\sim 2.3 \%$. TSFC is also reduced at takeoff and climb, but this is primarily due to the power added to the low spool power by the low spool motor/generator.

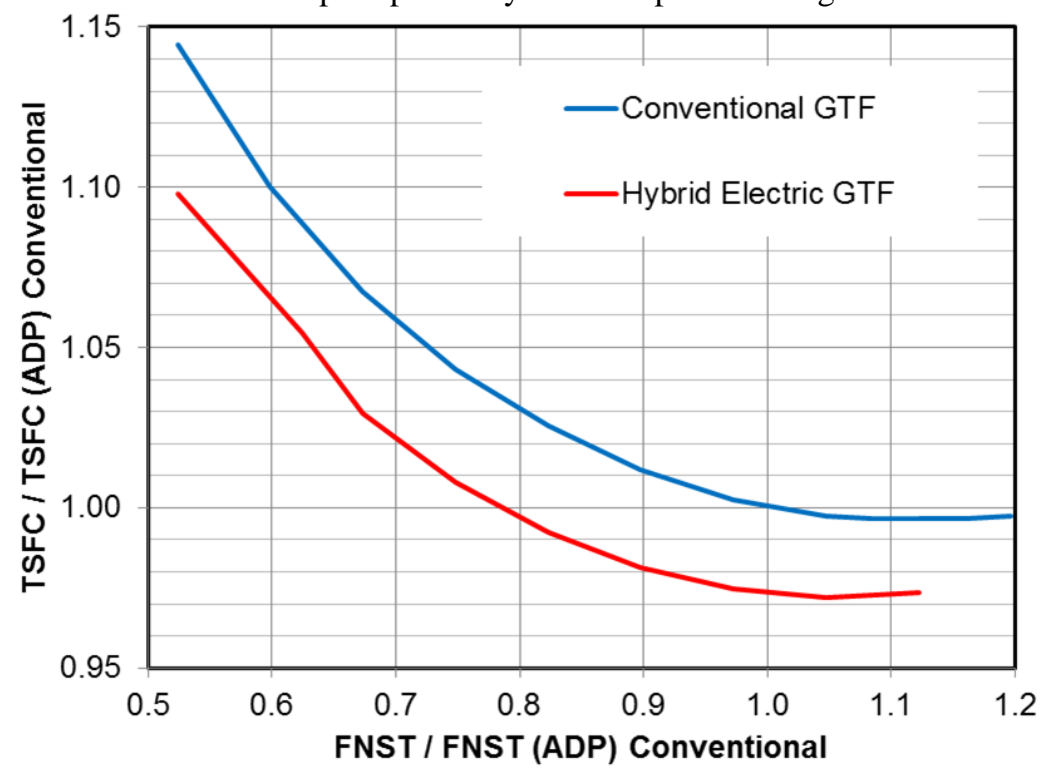

Figure 3: TSFC Improvement at Cruise for hGTF

The design and performance parameters of the hGTF engine resulting from this design procedure are provided in Table 3. Comparing Table 2 and Table 3, the notable differences between the hGTF and cGTF are BPR (21.7 v 17.6 at MCR) and core size ( $0.84 \mathrm{v} 1.01$ at MCR), as well as the TSFC $(0.250 \mathrm{v} 0.301$ at MTO, $0.419 \mathrm{v} 0.499 \mathrm{MCL}$, and 0.468 v 0.479 at MCR).

Table 3: hGTF Design and Performance Parameters

\begin{tabular}{|c|c|c|c|c|c|c|c|c|c|c|c|c|} 
& $\begin{array}{c}\text { Alt } \\
(\mathrm{kft})\end{array}$ & Mach & $\begin{array}{c}\Delta \mathrm{T}_{\text {AMB }} \\
(\mathrm{F})\end{array}$ & $\begin{array}{c}\text { Req } \\
\text { Thrust }\end{array}$ & $\begin{array}{c}\text { Actual } \\
\text { Thrust }\end{array}$ & $\begin{array}{c}\text { TSFC } \\
\text { Thorm }\end{array}$ & $\begin{array}{c}\text { OPR } \\
\text { CORSZ }\end{array}$ & FPR & BPR & $\begin{array}{c}\text { T4 } \\
(\mathrm{F})\end{array}$ & ETAC \\
\hline ADP & 35 & 0.74 & 0 & 3145 & 3145 & 0.467 & 0.85 & 55.1 & 1.29 & 22.4 & 0.92 & 0.539 \\
\hline MCL & 35 & 0.74 & 18 & 3930 & 3930 & 0.419 & 0.86 & 62.2 & 1.35 & 21.0 & 0.96 & 0.635 \\
\hline MTO & 0 & 0.25 & 27 & 16592 & 16592 & 0.250 & 0.82 & 51.3 & 1.28 & 22.9 & 1.00 & 0.602 \\
\hline SLS & 0 & 0 & 27 & 21943 & 23894 & 0.165 & 0.82 & 48.0 & 1.27 & 22.4 & 0.97 & 0.603 \\
\hline MCR & 35 & 0.74 & 0 & 3538 & 3538 & 0.468 & 0.84 & 59.8 & 1.32 & 21.7 & 0.96 & 0.546 \\
\hline
\end{tabular}

\section{System Weights}

The propulsion system analysis provides the performance benefit of the hGTF propulsion system. Balancing this benefit is the weight penalty incurred by implementing the system. The two major sub-systems adding to system weight are the Electric Energy Storage \& Conversion Systems (EES\&CS) and the Thermal Management System (TMS).

\section{A. Electric Energy Storage \& Conversion (EES\&C) System}

The electric energy storage requirements are derived from the takeoff and climb requirements, where the electric energy storage system must provide boost power to the propulsion system, and provide primary power to the subsystems, and TMS. There is also electrical energy required during the step climb of the capability mission. This energy could come from ground power or from the LS motor/generator during the first cruise segment, where the 
propulsion system could be used to charge the battery. The former option requires more battery capacity/weight and the latter requires slightly more Jet-A fuel burn during cruise. Only the stored energy required for takeoff and climb is used for battery weight estimates. Error! Reference source not found. provides the stored energy requirement during takeoff and climb (left chart) and step climb (right chart). $1295 \mathrm{~kW}-\mathrm{hr}$ is required at the low spool to provide boost power to the fan during takeoff and climb, but $1495 \mathrm{~kW}-\mathrm{hr}$ is required at the stored energy system output to overcome motor, motor drive and feeder losses, and to supply the subsystems power. The subsystems are powered by the battery during takeoff and climb. The motor, motor drive and feeder efficiencies are the 10 year horizon values provide in middle column of the component performance data section (left data table) of Table 4.
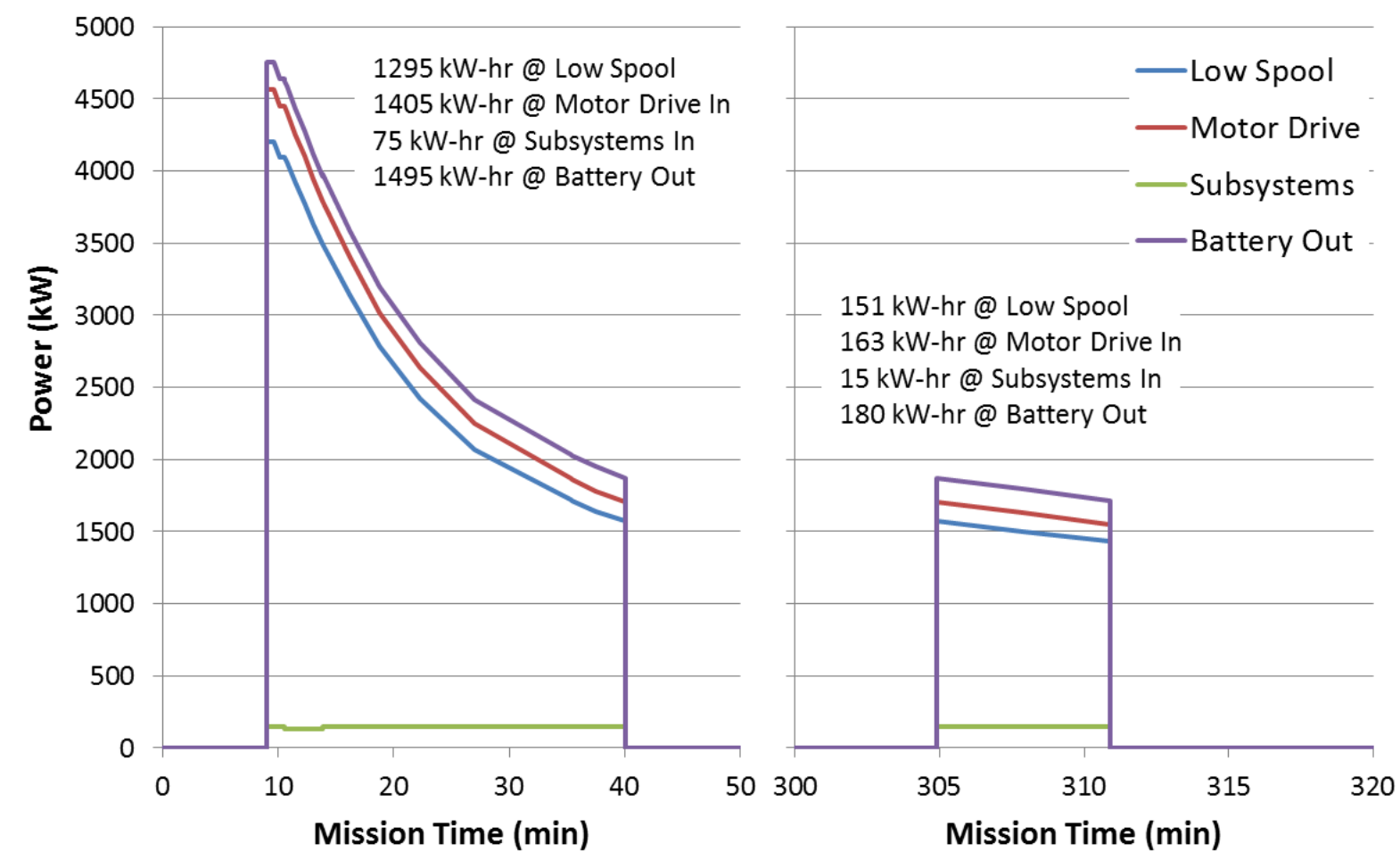

Figure 4: Stored Energy Requirements for the hGTF Based Aircraft

This analysis has been executed with the propulsion system providing max rated power at takeoff and climb. With a conventional gas turbine engine, minimal fuel burn results from a steep rapid climb so that cruising altitude is reached as soon as possible. The takeoff length is shorter and climb rate are even steeper for the shorter $900 \mathrm{~nm}$ DOC mission; but again for a cGTF airplane this mode of operation results in the lowest fuel burn. For the hGTF aircraft flying the $900 \mathrm{~nm}$ DOC mission, this scenario requires large motor boost power, but over a shorter time. A longer, more gradual climb requires less motor boost power, but over a longer time. An optimal may exist that reduces the battery storage energy requirement for the DOC mission. This will be considered in future studies. Note that this trade will not affect motor and motor drive size as they are sized to provide the needed boost power for the $3300 \mathrm{~nm}$ capability mission. Additionally, the analysis above provides the stored energy required for the capability mission. If a different optimal stored energy exists for the DOC mission, then removable battery packs would be required to realize the benefit.

The EES\&C system must provide $2102 \mathrm{~kW}$ to each propulsion system and $148 \mathrm{~kW}$ to the subsystems during takeoff. This results in a maximum required power from the stored energy source of $4758 \mathrm{~kW}((2102 * 2 / 0.94 / 0.98$ + 148) / 0.99). The EES\&C system must also have a stored energy capability of $1495 \mathrm{~kW}-\mathrm{hr}$ at the stored energy source output. Providing this capability with a hydrogen fueled PEM fuel cell (both liquid $\mathrm{H}_{2}$ and compressed $\mathrm{H}_{2}$ ) or a Li-ion battery (@200 W-hr/kg) is compared in Figure 5. Reference 3 provides a comprehensive energy density data set for various energy storage devices and systems. A sulfur free Jet-A fueled solid oxide fuel cell has also been considered, but at the required energy storage the system weight is $\sim 48,000 \mathrm{~kg}$ or $\sim 5 \mathrm{x}$ heavier than the Li-ion option. 


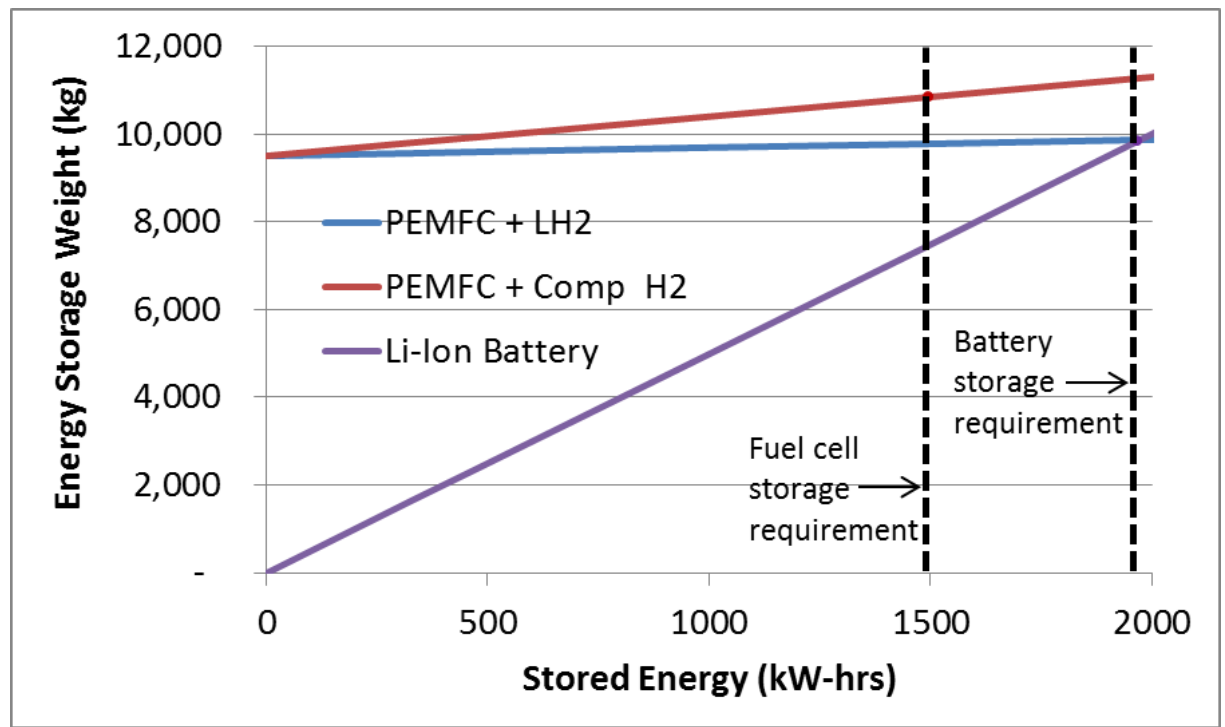

Figure 5: Weight Comparison between Li-Ion Battery and PEM Fuel Cell

Notice that the battery storage requirement is $1967 \mathrm{~kW}$-hr as opposed to that for the fuel cell at $1495 \mathrm{~kW}$-hr. This is because a battery cannot be fully discharged. It is assumed that with current technology the battery cannot be discharged to more than $20 \%$ of full charge. In addition, batteries do not discharge at $100 \%$ efficiency. Energy in excess of the requirement must be held in the battery at the time of discharge. This discharge efficiency is assumed at $95 \%$ with current technology. Thus $1967 \mathrm{~kW}-\mathrm{hr}$ is derived from $1495 \mathrm{~kW}-\mathrm{hr} / 0.8 / 0.95$. Improved excess discharge capacity and efficiency are considered in the EEC\&S weight analysis.

Error! Reference source not found. shows that batteries and a liquid $\mathrm{H}_{2}$ feed PEM fuel cell would be about the same weight, while the battery solution is lower weight than that of a compressed $\mathrm{H}_{2}$ feed PEM fuel cell. Future projections for fuel cells indicated $\sim 2 \mathrm{x}$ improvements in stack power density and $\mathrm{H}_{2}$ storage density, while 5 to $10 \mathrm{x}$ improvements are projected for battery technology. Thus the trade will be even more favorable for batteries with future technology and battery energy storage is selected over $\mathrm{H}_{2}$ feed PEM fuel cell energy storage.

Table 4 provides the weight analysis for the balance of the electric drive system. Estimates have been made for current component performance, mid-term (10 year horizon) and long-term (20 year horizon) project component performance, where the mid-term performance is just the average of the current performance and long-term projected performance (for the motor and motor drive). The 20 year horizon for the motor and motor drive are based on the goals for an ongoing NASA high density $1 \mathrm{MW}$ motor program $(8 \mathrm{hp} / \mathrm{lbm})$. Thus, there is no separate motor drive for the 20 year horizon system.

Table 4: Electric Energy Storage and Conversion System Weight

\begin{tabular}{|l||c|c|c|}
\hline Time Horizon & 20 & 10 & current \\
\hline \hline Component Performance & & & \\
\hline Motor & & & \\
\hline Power Density (kW/lbm) & 5.96 & 3.98 & 2.00 \\
\hline Efficiency & 0.96 & 0.94 & 0.92 \\
\hline Bi-Directional Converter & & & \\
\hline Power Density (lbm/kW) & 0 & 0.33 & 1 \\
\hline Efficiency & 1 & 0.98 & 0.96 \\
\hline Feeders & & & \\
\hline Voltage & 1080 & & \\
\hline Length (ft) & 50 & & \\
\hline Efficiency & 0.99 & 0.99 & 0.99 \\
\hline Energy Storage & & & \\
\hline Energy Density (W-hr/kg) & 1000 & 600 & 200 \\
\hline Efficiency & 0.97 & 0.96 & 0.95 \\
\hline Max Discharge & $90 \%$ & $85 \%$ & $80 \%$ \\
\hline
\end{tabular}

\begin{tabular}{|l||c|c|c|}
\hline Time Horizon & 20 & 10 & current \\
\hline \hline Component Weight & & & \\
\hline Motor & & & \\
\hline Power (kW) & 2102 & 2102 & 2102 \\
\hline Weight (lbm) & 353 & 528 & 1051 \\
\hline Bi-Directional Converter & & & \\
\hline Power (kW) & 2102 & 2145 & 2189 \\
\hline Weight (lbm) & 0 & 715 & 2189 \\
\hline Feeders & & & \\
\hline Current (amps) & & & \\
\hline Weight (lbm) & 353 & 530 & 706 \\
\hline & & & \\
\hline Energy Storage & & & \\
\hline Energy (kW-hr) & 1713 & 1832 & 1967 \\
\hline Weight (lbm) & 3768 & 6719 & 21641 \\
\hline Total Per Engine (lbm) & $\mathbf{5 1 7 9}$ & $\mathbf{1 0 2 6 3}$ & $\mathbf{2 9 5 3 3}$ \\
\hline
\end{tabular}




\section{B. Thermal Management System}

The conceptual design and weight analysis for TMS that services the EES\&C system and propulsion system has been completed. As for the EES\&C system itself, various technologies have been considered for the TMS. Error! Reference source not found. provides the basic TMS architecture along with the system flow rates and temperatures for the hot day takeoff design point. Hot day takeoff has the highest ambient conditions coupled with the highest system heat loads. The coolant loop (bottom left) provides cooling flow to the battery (Bat) and motor drive (MD). The primary architecture driver is the battery coolant maximum temperature limit, set at $140{ }^{\circ} \mathrm{F}$. Hot day fuel temperature is $120^{\circ} \mathrm{F}$, and with the limited flow rate of $1.1 \mathrm{lbm} / \mathrm{s}$, even the small load imposed by the mechanically driven fuel pump ( $21 \mathrm{~kW})$ heats the fuel to $153^{\circ} \mathrm{F}$, making it unsuitable as a heat sink for the battery coolant. The coolant loop is cooled with Ram Air (the only suitable heat sink as the engine fan air is $178{ }^{\circ} \mathrm{F}$ ) at the Ram Coolant Cooler (RCC). The propulsion system heat loads are cooled by the oil loop (center right), which include the accessory gearbox, GTF fan drive, GTF bearings, high spool starter generator, and the low spool motor/generator. All loads are serviced in parallel. The oil is cooled first at the fuel oil cooler (FOC), rejecting as much heat as possible to fuel and the remaining heat is rejected at the air oil cooler (AOC) to fan air. This is desirable as hot fuel has a thermodynamic benefit to the engine cycle and the more heat rejected to fuel, the less heat that is rejected to the AOC, resulting in lower overall heat exchanger weight and lower required fan air for lower fan stream losses (which have to be overcome with more propulsor fan power).

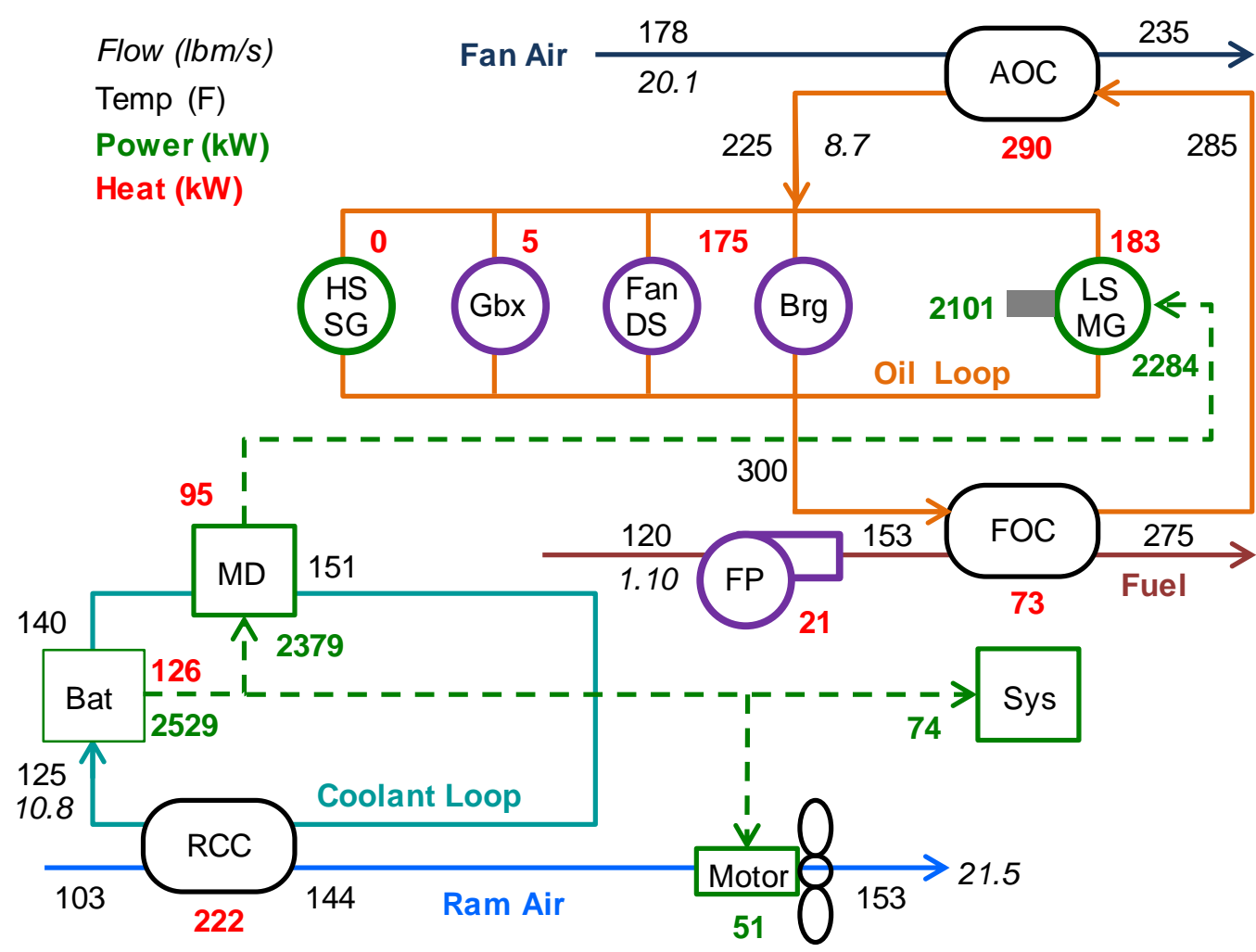

Figure 6: TMS Architecture and Design Condition State Points for Current Horizon Component Efficiencies and Temperature Capability

The heat loads, flow rates, and temperatures shown in Error! Reference source not found. are for the current component efficiencies from Table 4 . With the battery maximum coolant temperature set at $140{ }^{\circ} \mathrm{F}, 21.5 \mathrm{lbm} / \mathrm{s}$ of ram air is required to cool the coolant loop. With little ram recovery pressure during takeoff, a $51 \mathrm{~kW}$ fan is required to pull the air through the AOC, which adds a load to the battery. Considering the $2379 \mathrm{~kW}$ propulsor motor drive load, the $74 \mathrm{~kW}$ systems load, the $51 \mathrm{~kW}$ ram fan load, and a feeder efficiency of $0.99,2529 \mathrm{~kW}$ is required at the battery output. At $95 \%$ efficiency, $126 \mathrm{~kW}$ of heat is rejected to coolant by the battery. At $96 \%$ efficiency, the motor drive rejects $95 \mathrm{~kW}$ of heat to coolant. This heat load drives the need for $21.5 \mathrm{lbm} / \mathrm{s}$ of ram air.

At $1.1 \mathrm{lbm} / \mathrm{s}$ and a maximum temperature of $275^{\circ} \mathrm{F}$, there is $94 \mathrm{~kW}$ of heat rejection capacity in the fuel. $21 \mathrm{~kW}$ of this capacity is consumed by the mechanically driven fuel pump, leaving $73 \mathrm{~kW}$ of heat rejection from the

8

American Institute of Aeronautics and Astronautics 
propulsion system oil loop to fuel at the FOC. At 92\% efficiency, the LS motor/generator rejects $183 \mathrm{~kW}$ to oil. This load, along with the other engine loads sums to $363 \mathrm{~kW}$. With $73 \mathrm{~kW}$ rejected at the FOC, the remaining $290 \mathrm{~kW}$ is rejected at the AOC, driving the need for $20.1 \mathrm{lbm} / \mathrm{s}$ of fan air.

The heat exchangers and motor driven fan have been sized for the current component horizon. Error! Reference source not found. (first data column) provides the weight and required heat sink flow results. The RCC at $309 \mathrm{lbm}$, represents over $80 \%$ of the total TMS weight. This is due to the relatively low maximum battery coolant temperature of $140{ }^{\circ} \mathrm{F}$, which is relatively close to the available ram heat sink temperature of $103{ }^{\circ} \mathrm{F}$. Error! Reference source not found. provides the impact on AOC weight (and fan power) as the battery maximum coolant temperature is increased to $180^{\circ} \mathrm{F}$, which represents an increase in battery performance. Increasing this temperature by $20^{\circ} \mathrm{F}$ drops the RCC weight by $50 \%$.

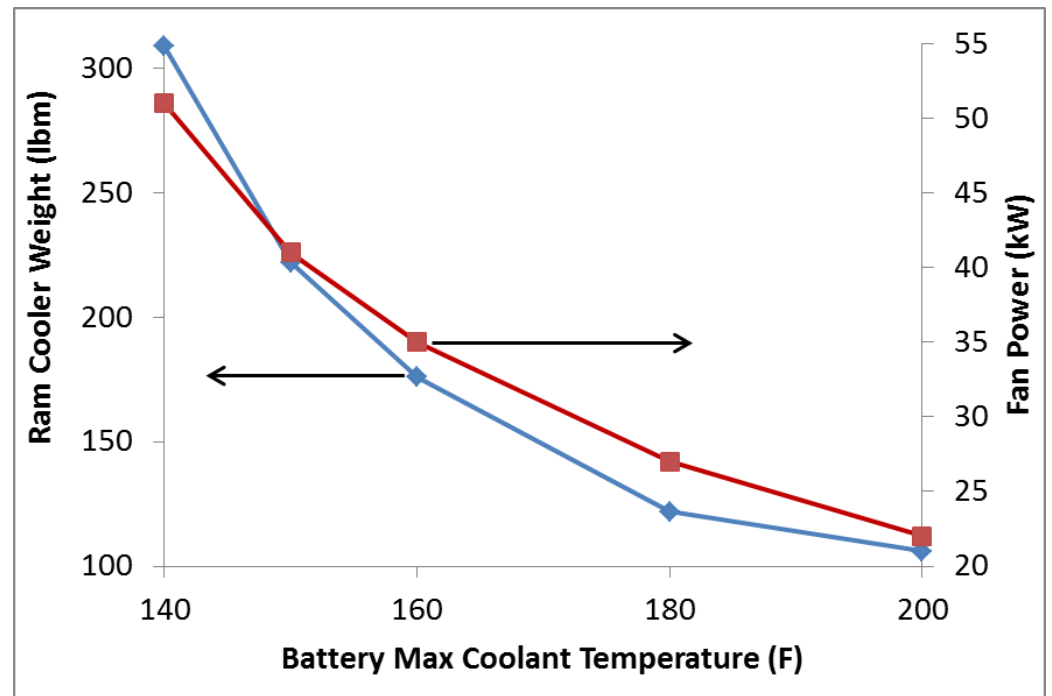

Figure 7: RCC Weight and Ram Fan Power Draw versus Battery Temperature Capability

Other technologies that could decrease the TMS weight include electric engine accessories and high temperature fuel. Mechanically driven fuel pumps operate at a fixed gear ratio to the engine high spool, producing flow far in excess of the demand for most operating conditions. Fuel flow in excess of demand is circulated around the pump and back into the inlet, resulting in a very low pump efficiency and high heat rejection to fuel. A variable speed electrically driven pump would be controlled to deliver only demand flow, and thus have a high efficiency and low heat rejection to fuel. High temperature capable fuel $\left(345^{\circ} \mathrm{F}\right)$ and oil $\left(350{ }^{\circ} \mathrm{F}\right)$ enable higher heat rejection to the relatively light FOC, reducing the size and fan air flow required at the AOC. Error! Reference source not found. shows the heat loads, ram flow rate and fan air flow rates, for a TMS incorporating high temperature fuel, an electrically driven demand fuel pump and $160^{\circ} \mathrm{F}$ maximum battery maximum coolant temperature, with 10 hear horizion component efficiencies. The fourth data colum of Table 5 provides the corresponding component weights and ram and fan air flow rates. Compared to the current horizion (data colum 1), the combined FOC \& AOC weight is decreased by 55\% and ram flow and fan flow are decreased by 53\% and 69\% respectively. Error! Reference source not found. also provides the TMS weights, ram air flow rates and fan air flow rates for the current, mid-term 10 year horizon and long-term 20 year horizon component efficiencies with various combinations of electric demand fuel pump, high temperature fuel and high temperature battery technologies. 


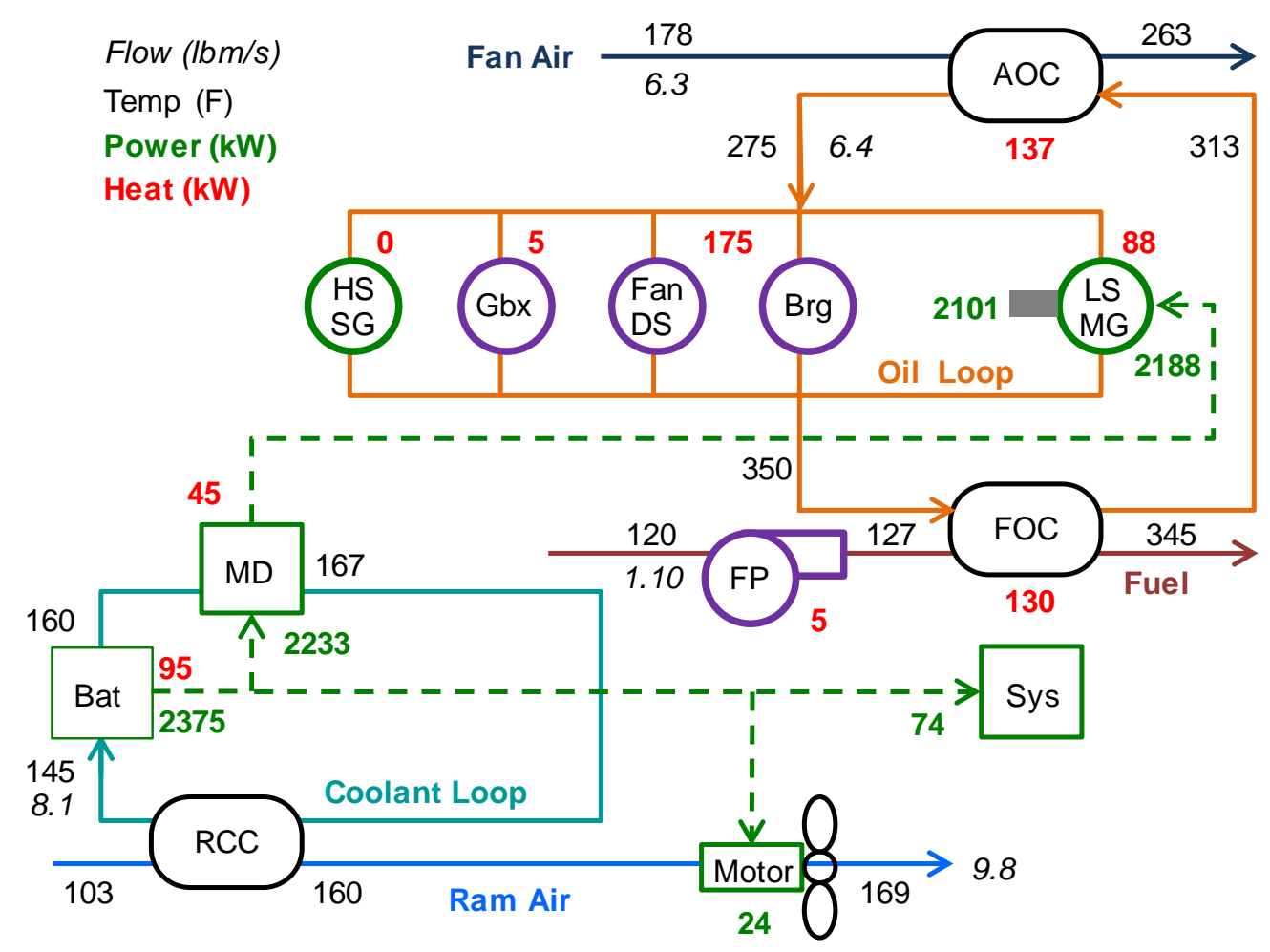

Figure 8: Design Condition State Points for 10 year Horizon Component Efficiencies with High Temperature Fuel Capability and Electric Fuel Pump Technology and High $160^{\circ} \mathrm{F}$ Battery Coolant Capability

Table 5: TMS Air Flow \& Weights

\begin{tabular}{|l|c||c|c|c||c|c|}
\hline & Current & Current $^{*}$ & 10 Year $^{*}$ & 10 Year $^{*}, \#$ & 20 Year $^{*}$ & 20 Year $^{*}, \#$ \\
\hline \hline Battery Heat $(\mathrm{kW})$ & 126 & 126 & 95 & 95 & 68 & 68 \\
\hline Motor Drive Heat $(\mathrm{kW})$ & 95 & 95 & 45 & 45 & 0 & 0 \\
\hline LS Motor/Gen Heat $(\mathrm{kW})$ & 183 & 183 & 88 & 88 & 43 & 43 \\
\hline Max Coolant Temp (F) & 140 & 140 & 140 & 160 & 140 & 160 \\
\hline Max Fuel Temp (F) & 275 & 345 & 345 & 345 & 345 & 345 \\
\hline Ram Air Flow $(\mathrm{lbm} / \mathrm{s})$ & 21 & 21 & 15 & 9.8 & 9.1 & 5.4 \\
\hline Fan Air Flow $(\mathrm{lbm} / \mathrm{s})$ & 20 & 10 & 6.3 & 6.3 & 4.7 & 4.7 \\
\hline RCC Weight $(\mathrm{lbm})$ & 309 & 309 & 181 & 105 & 78.6 & 50 \\
\hline FOC Weight $(\mathrm{lbm})$ & 5 & 8 & 9 & 9 & 10 & 10 \\
\hline AOC Weight $(\mathrm{lbm})$ & 51 & 27 & 16 & 16 & 11 & 11 \\
\hline Ram Fan Weight $(\mathrm{lbm})$ & 26 & 26 & 18 & 12 & 11 & 7 \\
\hline \hline Total $(\mathrm{lbm})$ & $\mathbf{3 9 1}$ & $\mathbf{3 6 9}$ & $\mathbf{2 2 4}$ & $\mathbf{1 4 3}$ & $\mathbf{1 1 1}$ & $\mathbf{7 8}$ \\
\hline
\end{tabular}

* includes high temp fuel and electric fuel pump

\# includes $160^{\circ} \mathrm{F}$ maximum battery coolant temperature (as opposed to $140^{\circ} \mathrm{F}$ maximum battery coolant temperature)

\section{Benefits}

As discussed in the "Study Baseline Vehicle and Engine" Section 2.0, the baseline vehicle is the N+4 2035 "Refined SUGAR" airframe powered by a second generation conventional GTF engine. The hybrid electric vehicle alternative replaces the cGTF with and hGTF, and adds the weight difference of the hGTF propulsion system (compared to the $\mathrm{CGTF}$ ), and the EES\&C system and TMS weight. The analysis is executed for a fixed vehicle (both vehicles are held at the same TOGW), so as weight is added, fuel carrying capacity is reduced. Thus, the thrust requirements are the same for both the cGTF and hGTF engines. 
Alternatively, a rubber vehicle model could be used (TOGW allowed to grow) such that each vehicle is sized to provide the same maximum range for the capability mission. The process for determining the overall fuel burn and energy consumption benefit requires an iterative analysis. First, thrust requirements are selected for the hGTF engine. The engine is sized for cruise, the LS motor/generator, EES\&C system power and energy requirements are determined, and the systems are sized. The hGTF aircraft is then flown through the capability mission to determine the total mission. If the range requirement is not met, the vehicle is upsized and new thrust requirements are selected. The above process is iterated until convergence is achieved. As implied in the EES\&C system and TMS weight analysis above, the weight of these systems is very uncertain and will be decreasing as new technology matures. Thus, the fixed vehicle model has been run parametrically, with added weight as an independent variable.

Figure 9 provides the results of the mission vehicle analysis. The hGTF reduces Jet-A fuel burn both during cruise due to the improved engine TSFC, and during takeoff and climb as stored electric energy is providing some of the shaft power to drive the fan. Consider first Figure 9a, which provides the capability mission range of the hGTF vehicle compared to the cGTF vehicle $(3300 \mathrm{~nm}$ ). If the hGTF implementation comes with no weight increase (no added weight for the electric energy storage and conversion (EES\&C) system, thermal management system (TMS) or the LS motor), a $200 \mathrm{~nm}$ range benefit is realized. As weight is added, fuel is displaced on the fixed vehicle and range is decreased. The figure shows that the hGTF vehicle provides a capability range benefit only if the added weight is less than $1200 \mathrm{lbm}$. Some compromise on capability mission range may be acceptable if the DOC mission fuel burn reduction is judged significant.

Consider now Figure 9b, which provides the $900 \mathrm{~nm}$ DOC mission fuel burn of the hGTF vehicle compared to the cGTF vehicle $(6630 \mathrm{lbm})$. Again, if the hGTF implementation comes with no weight increase, a $580 \mathrm{lbm}$ fuel burn benefit is realized. As weight is added, fuel must be added to carry the weight. The figure shows that the hGTF vehicle provides a DOC mission fuel burn benefit all the way up to an added weight of $\sim 16000 \mathrm{lbm}$.
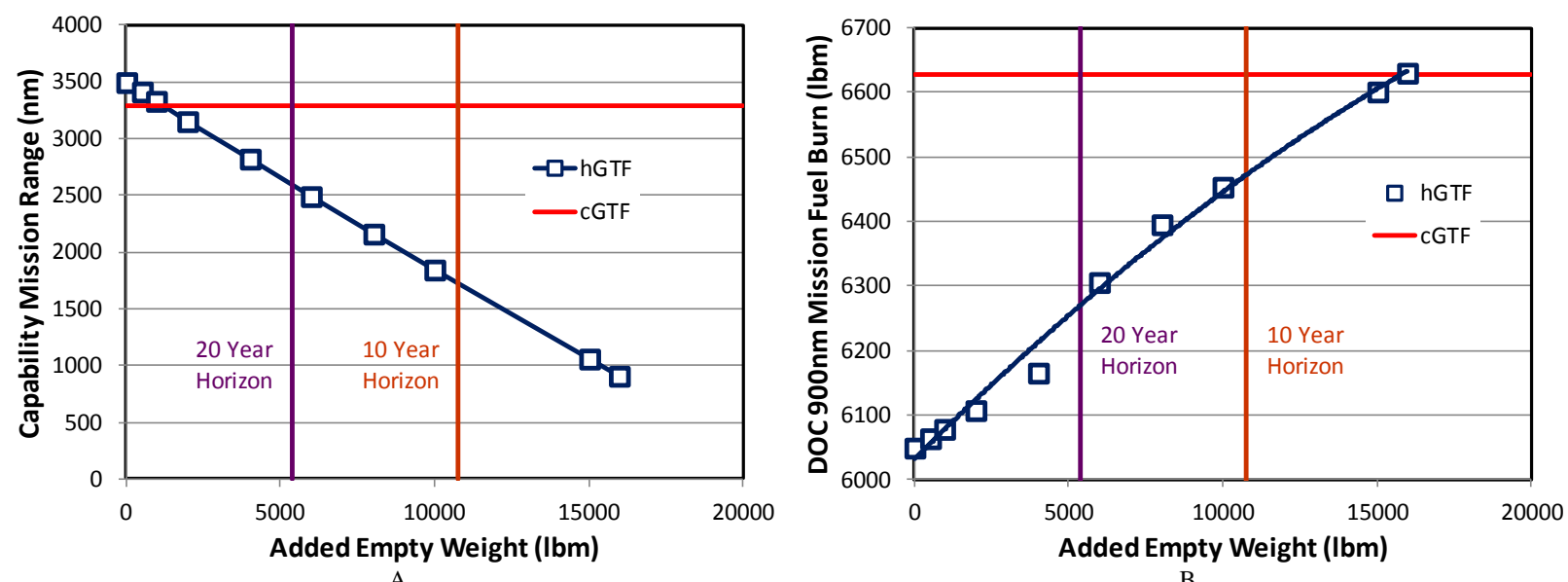

Figure 9: Range and Fuel Burn Benefits for the hGTF Based Aircraft at 10 and 20 Year Technology Horizons

Also shown on Figure 9 are estimates of the EES\&C system, TMS and LS motor at various technology levels. At the most aggressive technology horizon, the total weight increase of the hGTF system is estimated at $\sim 5400 \mathrm{lbm}$. The hGTF vehicle suffers from a $690 \mathrm{~nm}_{-}(21 \%)$ range decrease for the capability mission at this weight, but can provide a $360 \mathrm{lbm}(5 \%)$ Jet-A fuel burn decrease for the DOC mission.

This Jet-A fuel burn decrease includes "free" energy in the batteries charged on the ground. The equivalent Jet-A fuel burn to provide $1495 \mathrm{~kW}-\mathrm{hr}$, at the typical electric power specific fuel consumption of a large gas turbine engine operating at a peak thermal efficiency $(\sim 0.27 \mathrm{lbm} / \mathrm{hr} / \mathrm{kW})$ is $\sim 400 \mathrm{lbm}$, approximately the same as the in air Jet-A fuel burn reduction. Figure 10 shows the fuel burn with the fuel consumption for ground charging included (green line). Thus accounting for the ground energy consumption/ $/ \mathrm{CO}_{2}$ emissions, the hGTF aircraft at the 20 year technology horizon is approximately energy consumption/ $\mathrm{CO}_{2}$ emissions neutral compared to cGTF aircraft. 


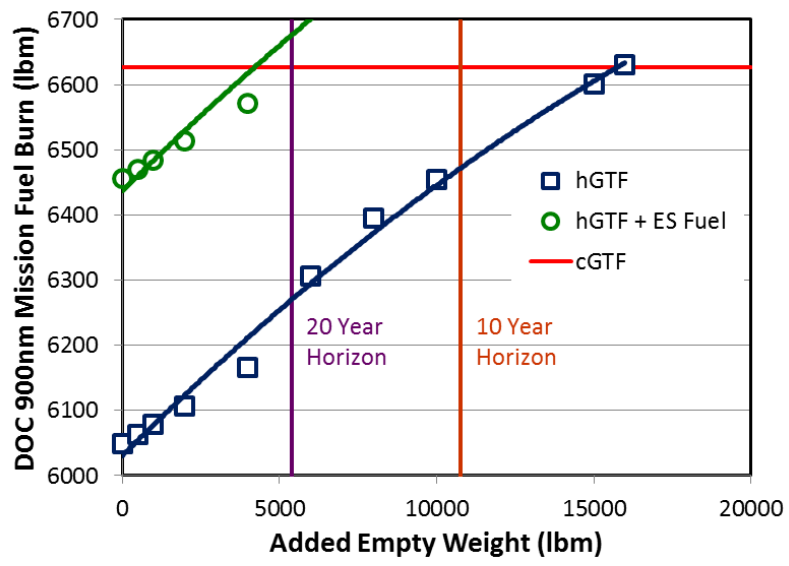

Figure 10: Fuel Burn (Including both Airborne and Ground) Benefits Analysis for the hGTF Based Aircraft at 10 and 20 Year Technology Horizons

\section{Conclusion}

This study has investigated the potential benefits of using stored electric power to provide boost power, through a low spool mounted motor, for an engine core sized and optimized to provide maximum cruise thrust. Such an hGTF propulsion system provides a modest improvement in cruise TSFC, $2.3 \%$, but has an aircraft level power deficit of 4.2 MW at take-off. With aggressive assumptions for future battery, electric system and thermal management system weight and performance, it has been shown that a 5\% reduction in aircraft $900 \mathrm{~nm}$ DOC mission fuel burn is possible. However, with the fuel burn required to charge batteries is included, there is no fuel burn reduction.

This improvement alone is not enough to motivate a radical change in propulsion system technology. If community noise becomes a major issue, this approach can substantially reduce taxi-way noise through the electric taxi operating mode. In addition, the study does highlight that there is a hybrid gas-electric system architecture that can provide both an aircraft and overall (including fuel for battery charging) fuel burn benefit. Thus, future study in other alternative architectures $[4,5]$ is recommended.

\section{Acknowledgments}

The material provided in this document is based upon work supported by the National Aeronautics and Space Administration under Contract Number NNC14CA32C.

Any opinions, findings and conclusions or recommendations expressed in this material are those of the author(s) and do not necessarily reflect the views of the National Aeronautics and Space Administration.

The authors wish to acknowledge Dan Kupratis and Bob Bengtson from Pratt \& Whitney and Pedro Canache and Bill Wicklund from United Technologies Aerospace Systems for the technical support in this research.

\section{References}

${ }^{1}$ Bradley, M. K., and Droney, C. K., "Subsonic Ultra Green Aircraft Research Phase I Final Report,” National Aeronautics and Space Administration Contractor Report NASA/CR-2011-216847, 2011.

${ }^{2}$ Bradley, M. K., and Droney, C. K., "Subsonic Ultra Green Aircraft Research Phase II: N+4 Advanced Concept Development," National Aeronautics and Space Administration Contractor Report NASA/CR-2012-217556, 2012.

${ }^{3}$ Rheaume, J. M., "Energy Storage for Commercial Hybrid Electric Aircraft," SAE 2016 Aerospace Systems and Technology Conference, SAE Hartford CT (submitted for publication) 
${ }^{4}$ Welstead, J.R. and Felder, J.L., "Conceptual Design of a Single-Aisle Turboelectric Commercial Transport with Fuselage Boundary Layer Ingestion," AIAA SciTech Conference, American Institute of Aeronautics and Astronautics, San Diego, CA, 2016, AIAA-2016-1027

${ }^{5}$ Jenson, R.H., Brown, G.V., Felder, J.L. and Duffy, K. P. "Turboelectric Aircraft Drive Key Performance Parameters and Functional Requirements," AIAA Propulsion and Energy Conference, American Institute of Aeronautics and Astronautics, Orlando, FL, 2015, AIAA-2015-3890 